\title{
Acquired predator recognition in juvenile rainbow trout (Oncorhynchus mykiss): conditioning hatchery-reared fish to recognize chemical cues of a predator
}

\author{
Grant E. Brown and R. Jan F. Smith
}

\begin{abstract}
In this study, we exposed predator-naive, hatchery-reared juvenile rainbow trout (Oncorhynchus mykiss) to the chemical stimuli from northern pike (Esox lucius) and either trout skin extract (a chemical alarm signal) or a distilled water control to test for acquired recognition of a novel predator. Trout exposed to conspecific skin extract and pike odour significantly increased antipredator behaviour (i.e., decreased foraging and area use and increased shoaling and freezing), while those exposed to distilled water and pike odour did not. Conditioned trout were exposed to pike odour alone (versus a distilled water control) either 4 or 21 days later. When presented with pike odour 4 days postconditioning, trout significantly increased antipredator behaviour (i.e., decreased foraging and area use and increased time under cover and freezing). Trout tested 21 days postconditioning still exhibited a significant increase in antipredator behaviours when presented with pike odour alone (i.e., decreased foraging and increased freezing). These data are the first to demonstrate that hatchery-reared trout can be conditioned to recognize the chemical cues of a predator and suggest that this may serve as a strategy to train hatchery-reared fish to recognize predators prior to stocking into natural waterways.
\end{abstract}

Résumé : Dans le cadre de la présente étude, nous avons utilisé des truites arc-en-ciel (Oncorhynchus mykiss) juvéniles d'élevage qui n'ont pas été exposées à la prédation (truites novices) pour les soumettre à des stimuli chimiques produits par le grand brochet (Esox lucius), et soit à des extraits de peau de truite (signal d'alarme chimique), soit à un témoin d'eau distillée afin de tester la reconnaissance acquise d'un nouveau prédateur. Les truites exposées à un extrait de peau de congénère et à l'odeur du brochet affichaient un comportement anti-prédateur plus marqué (c.-à-d., baisse de l'activité de recherche de nourriture et des déplacements dans l'aire et augmentation du regroupement et de la station immobile), tandis que les truites exposées à de l'eau distillée et à l'odeur du brochet ne présentaient pas ce comportement. Les truites conditionnées ont été exposées à l'odeur du brochet seulement (par rapport à un témoin d'eau distillée) 4 ou 21 jours plus tard. Lorsque les sujets ont été exposés à l'odeur de brochet 4 jours après leur conditionnement, leur comportement anti-prédateur s'est intensifié significativement (c.-à-d., baisse de l'activité de recherche de nourriture et du déplacement dans l'aire et augmentation du temps passé à l'abri et en station immobile). Les truites testées 21 jours après leur conditionnement présentaient encore un comportement anti-prédateur assez marqué lorsqu'elles étaient exposées à l'odeur de brochet seulement (c.-à-d., baisse de l'activité de recherche de nourriture et augmentation de la durée en station immobile). Il s'agit des premières données qui montrent que l'on peut conditionner des truites d'élevage à reconnaître les signaux chimiques émis par un prédateur; cela pourrait constituer une stratégie d'entraînement des poissons d'élevage à reconnaître des prédateurs avant leur ensemencement dans des cours d'eau naturels.

[Traduit par la Rédaction]

\section{Introduction}

Hatchery-reared fishes, in particular salmonids, are routinely stocked into natural waterways in an attempt to restore or maintain stable populations. One of the major pitfalls of these stocking programmes are the dramatic levels of mortality of newly stocked individuals (Suboski and Templeton 1989). These high levels of mortality can be attributed to naive

Received January 15, 1997. Accepted June 30, 1997. J13829

G.E. Brown ${ }^{1}$ and R.J.F. Smith. Department of Biology, 112 Science Place, University of Saskatchewan, Saskatoon, SK S7K 5E2, Canada.

1 Author to whom all correspondence should be addressed. Mailing address: Department of Biological Sciences, Union College, Schenectady, NY 12308-2311, U.S.A. hatchery-reared individuals failing to recognize predators due to an inability to acquire this knowledge prior to stocking (Suboski and Templeton 1989). As a result, newly stocked individuals are at a higher risk of predation (Healey and Reinhardt 1991; Berejikian 1995; Shively et al. 1996).

Several attempts have been made to condition hatcheryreared salmonids to recognize potential predators, but have met with limited success. Previous attempts have focussed on either pairing an aversive stimulus (i.e., electric current) and a model predator (Thompson 1966; Kanayama 1968; Healey and Reinhardt 1991) or allowing naive fry to interact with a live predator (Kanid'hev et al. 1970).

Thompson (1966) conditioned 10000 chinook salmon (Oncorhynchus tshawytscha) fry using an electric current and then released them with untrained fish into a natural stream. $\mathrm{He}$ reported a reduction of mortality of only about $1 \%$ and decreased growth among conditioned versus unconditioned fish 
(Thompson 1966). Healey and Reinhardt (1991) conducted a similar study with coho (Oncorhynchus kisutch) and chinook salmon fry. They reported that while the conditioning was successful in training fry to avoid a model predator, no significant difference in survival was found when conditioned versus unconditioned fry were exposed to a live predator.

Many fishes have been shown to possess chemical alarm signals, localized in the skin (e.g., Smith 1992). These chemicals are generally only released through mechanical damage to the skin, as would occur during predation (Smith 1992). Damage-released alarm pheromones have been demonstrated in ostariophysans (Smith 1992) and in a number of other species, including darters (Smith 1979, 1982), gobies (Smith 1989; Smith et al. 1991), sculpins (Hugie et al. 1991), sticklebacks (Mathis and Smith 1993a; Brown and Godin 1997), poeciliids (García et al. 1992), and one salmonid (Brown and Smith 1997). When detected by nearby conspecifics (and some heterospecifics), these pheromones elicit an alarm response, characterized by an increase in a variety of antipredator behaviours, including dashing (or skittering), freezing, shelter use, shoaling, reduced foraging, and avoidance of areas where alarm signals have been detected (Heczko and Seghers 1981; Lawrence and Smith 1989; Krause 1993; Mathis and Smith 1993a, 1993b; Brown et al. 1995a, 1995b; Wisenden et al. 1995; Brown and Smith 1997).

Releaser-induced recognition learning involves the simultaneous exposure to aversive (releasing) stimulus and a neutral stimulus causing learned aversion to the neutral stimuli (Suboski 1990, 1992a, 1992b). The result of this learning mechanism is acquired predator recognition in which predatornaive individuals show appropriate antipredator behaviour to the cue of a potential predator even though they have had no direct exposure to the predator. Several authors have demonstrated such acquired predator recognition by pairing damagereleased alarm pheromones with the visual or chemical cue of a predator (e.g., Magurran 1989; Chivers and Smith 1994a, 1994b; Chivers et al. 1995).

Juvenile rainbow trout (Oncorhynchus mykiss) have recently been shown to possess a chemical alarm signal (Lebedeva et al. 1994; Brown and Smith 1997). When presented with conspecific skin extract, juvenile trout exhibit significant antipredator responses, including (i) increased time spent under cover, (ii) increased time to resume foraging, (iii) increased freezing, (iv) decreased number of food items consumed, and $(v)$ decreased area use. The purpose of this study was to determine (1) if juvenile hatchery-reared rainbow trout could be conditioned to show an alarm response to the chemical cues of a potential predator and (2) if this response is retained for an ecologically relevant period of time.

\section{Methods}

\section{Test fish}

Juvenile rainbow trout were obtained from Mainstream Hatcheries, Vanscoy, Sask., Canada. Trout were housed in 300-L Living Stream recirculating holding tanks at $\sim 15^{\circ} \mathrm{C}$ and a $14 \mathrm{~h}$ light : $10 \mathrm{~h}$ dark cycle. Fish were fed ad libitum daily with commercial trout food and provided supplemental feedings three times per week with frozen adult brine shrimp (Artemia franciscana).

Northern pike (Esox lucius) were collected from Pike Lake and Eagle Creek $(\sim 35 \mathrm{~km}$ south and $45 \mathrm{~km}$ west of Saskatoon, Sask., respectively) using seine nets. Pike were held in $60-\mathrm{L}$ aquaria at $\sim 14^{\circ} \mathrm{C}$ under a $14 \mathrm{~h}$ light : $10 \mathrm{~h}$ dark cycle and were fed one or two fathead minnows (Pimephales promelas) every 3 days.

\section{Stimulus collection}

Trout skin extract (TSE)

We used 14 juvenile rainbow trout (mean $\pm \mathrm{SD}=5.06 \pm 0.40 \mathrm{~cm}$ standard length) to generate the TSE. Trout were killed with a blow to the head (in accordance with the Canadian Council on Animal Care guidelines) and the skin removed from both sides of the body, rinsed in glass-distilled water (to remove any unwanted tissue), and placed in $50 \mathrm{~mL}$ of chilled glass-distilled water. A total of $49.18 \mathrm{~cm}^{2}$ of skin was collected. We homogenized the skin, filtered it through glass wool, and added glass-distilled water to bring the final volume to $400 \mathrm{~mL}$. The stimulus water was frozen in $30-\mathrm{mL}$ samples at $-20^{\circ} \mathrm{C}$ until required. As a control, we also froze $30-\mathrm{mL}$ samples of glassdistilled water.

\section{Pike odour (PO)}

Prior to experiments, two northern pike (16.2 and $18.9 \mathrm{~cm}$ fork length) were fed a volume of 4.0-4.5 mL (measured by volumetric displacement in water) of green swordtail (Xiphophorus helleri) every 3 days for four consecutive feedings. Swordtails were used as a control diet because they lack any known alarm pheromones (Mathis and Smith $1993 b$ ), and rainbow trout do not show any reaction to swordtail skin extract (Brown and Smith 1997). One hour after the final feeding, the pike were removed from their holding tanks, rinsed with dechlorinated tap water (to remove any residual scales or skin from the swordtails), and placed into an identical holding tank containing fresh, dechlorinated tap water. Twelve hours later, the pike were placed into Plexiglas stimulus collection chambers $(26 \times 8 \times 8 \mathrm{~cm})$ that contained $\sim 1200 \mathrm{~mL}$ of dechlorinated tap water. The chambers were aerated, but not filtered. Forty-eight hours later, the pike were removed and all water in the collection chambers was filtered through glass wool and pipetted into 30-mL samples. Pike stimulus samples were frozen at about $-20^{\circ} \mathrm{C}$ until testing.

\section{Experiment 1. Conditioning trials}

We tested six groups of five juvenile rainbow trout (mean $\pm \mathrm{SD}=$ $6.86 \pm 0.65 \mathrm{~cm}$ standard length) for both control and experimental treatments in $110-\mathrm{L}$ aquaria. Each of the test tanks contained cover consisting of a ceramic tile $(9.8 \times 20 \mathrm{~cm})$ mounted on three cylindrical glass legs $(5.5 \mathrm{~cm}$ in height) and a silica sand substrate $\sim 4 \mathrm{~cm}$ deep. A single airstone was mounted in the centre of an end wall, and a length of airline tubing terminated near the airstone. This tube was used to introduce chemical stimuli. An additional length of airline tubing was placed in the centre of the opposite end wall and was used to deliver food items (frozen brine shrimp) to the test tank.

Conditioning trials consisted of a 10 -min prestimulus and a 10 -min poststimulus observation period. During pre- and poststimulus periods, we introduced five previously frozen adult brine shrimp every minute (total of 100 shrimp per trial). Throughout the observation periods, we recorded (i) time until the first food item was consumed, (ii) number of individuals that consumed a food item, (iii) total number of food items consumed, (iv) area use, $(v)$ shoaling index, and $(v i)$ the frequency of occurrence of freezing behaviour. Area use was recorded as the mean position of all five trout $(1=$ back of tank, near the cover, $2=$ centre area, and $3=$ front of tank, near the food delivery tube) and was recorded every $15 \mathrm{~s}$. Shoaling index was also recorded every $15 \mathrm{~s}$ and scored from 1 (no individual within two body lengths of another) to 5 (all individuals within two body lengths of each other). Freezing was defined as when an individual ceased all movement, settled to the subtrate, and remained motionless for at least $30 \mathrm{~s}$.

Prior to the prestimulus period, we removed $60 \mathrm{~mL}$ of water through the stimulus injection tube and discarded it (to remove any 
Fig. 1. Change in response to DW + PO (open bars) and to TSE + PO (solid bars) for each of the behavioural measures recorded in experiment 1. *Significant difference at $P<0.05$ (Mann-Whitney $U$-test) between DW + PO control and TSE + PO experimental trials. Data are presented as mean \pm SE for clarity. Nonparametric statistics were used for the analysis (see text for details).

(A) Time to capture first food

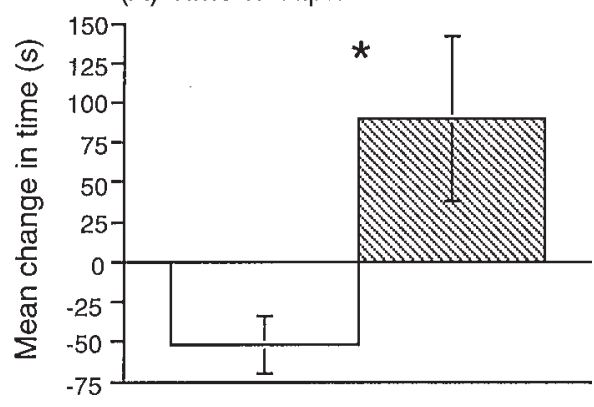

(C) Individuals eating

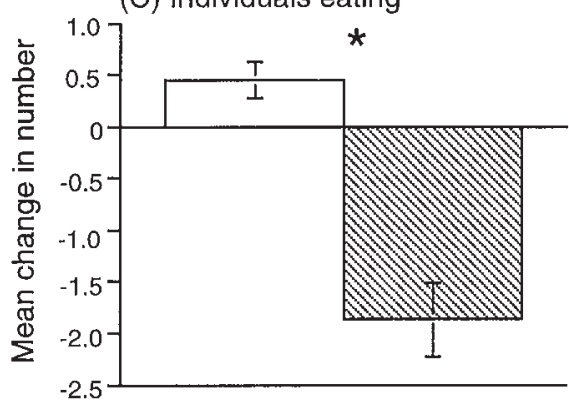

(E) Shoaling index

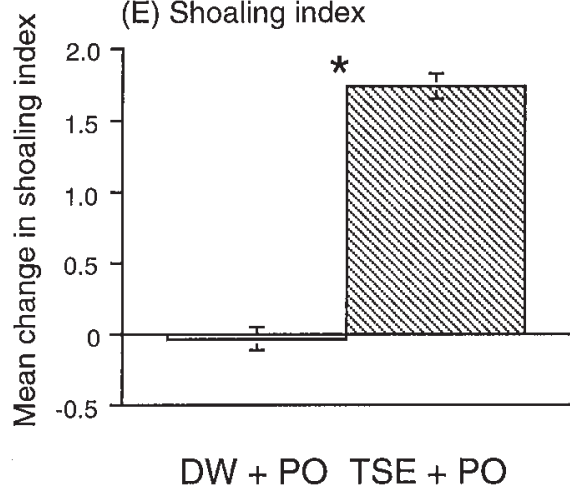

stagnant water remaining in the tube). We then removed an additional $60 \mathrm{~mL}$ of water and retained it. After the prestimulus observation period, we injected $30 \mathrm{~mL}$ of TSE and $30 \mathrm{~mL}$ of PO. For control trials, we injected $30 \mathrm{~mL}$ of distilled water (DW) and $30 \mathrm{~mL}$ of PO. Each group received both the DW + PO and TSE + PO treatments; thus, each group serves as its own control. Control trials began at $\sim 8: 30$ a.m., and experimental trials began at 1:00 p.m. Control trials were always conducted in the morning because any response to the experimental stimulus may have masked a response to the control stimulus (Smith 1982; Hazlett 1997).

For each behavioural measure, we calculated the difference between pre- and post-stimulus observation periods. We then compared the differences for control and experimental treatments using a Mann-Whitney $U$-test (Siegel 1956).

\section{Experiment 2. Acquired predator recognition, 4 days postconditioning}

The purpose of this portion of the study was to determine if trout had acquired the ability to recognize a potential predator after a single exposure to conspecific skin extract and predator odour.
(B) Food items eaten

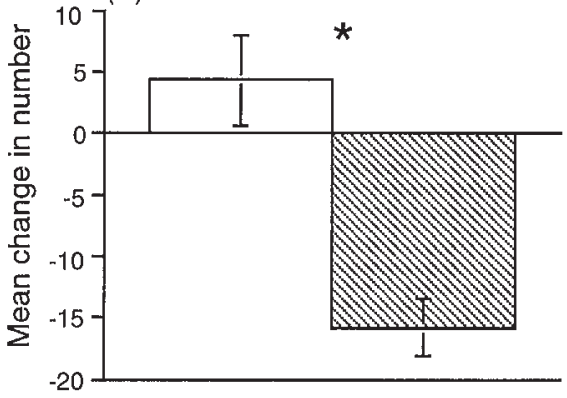

(D) Area use

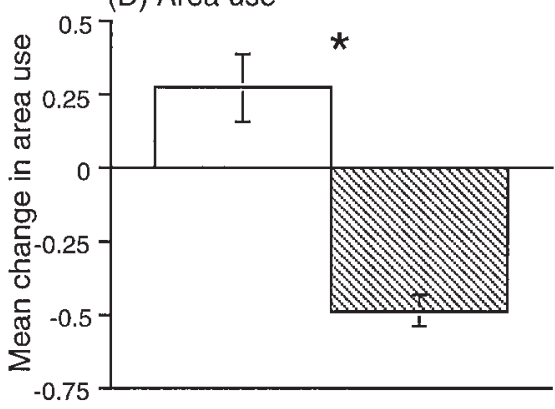

(F) Individuals freezing

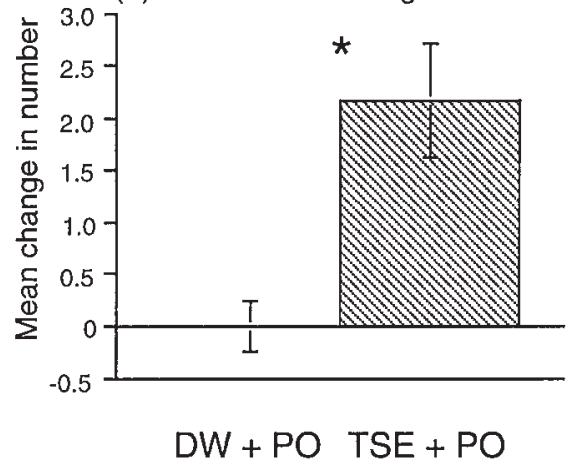

It has been shown that fathead minnows may show a fright response to a neutral stimulus if that stimulus is presented in the same manner as a previously alarming stimulus (Mathis and Smith 1993b). To eliminate this possible confound, we modified the social context and test tanks for experiments 2 and 3.

After each of the conditioning trials, three of the five trout from each tank of "conditioned" fish (chosen arbitrarily) were transferred to individual test tanks. The remaining two of five trout from each conditioning trial were transferred to a 60 -L holding tank for use in experiment 3 . Trout in the holding tank were fed ad libitum daily as described above.

Trout were placed individually in a series of 37-L test tanks. Each tank contained an airstone and stimulus injection and food delivery tubes as described in experiment 1 . Test tanks also contained a cover object (as described in experiment 1) and a substrate of silica sand $\sim 4 \mathrm{~cm}$ deep.

Control and experimental trials consisted of a 10-min prestimulus and a 10-min poststimulus observation period. Prior to the prestimulus observation period, we removed and retained $60 \mathrm{~mL}$ of water as described in experiment 1 . We presented one adult brine shrimp every 
Fig. 2. Change in response to DW (open bars) and to PO (solid bars) for each of the behavioural measures recorded in experiment 2. *Significant difference at $P<0.05$ (Mann-Whitney $U$-test) between DW control and PO experimental trials. Data are presented as mean \pm SE for clarity. Nonparametric statistics were used for the analysis (see text for details).

(A) Time to capture first food

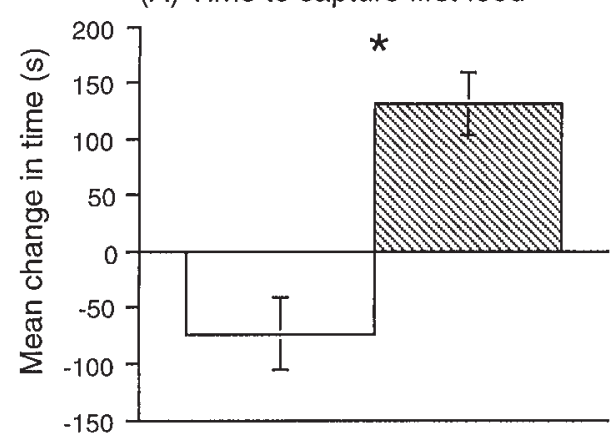

(C) Time under cover

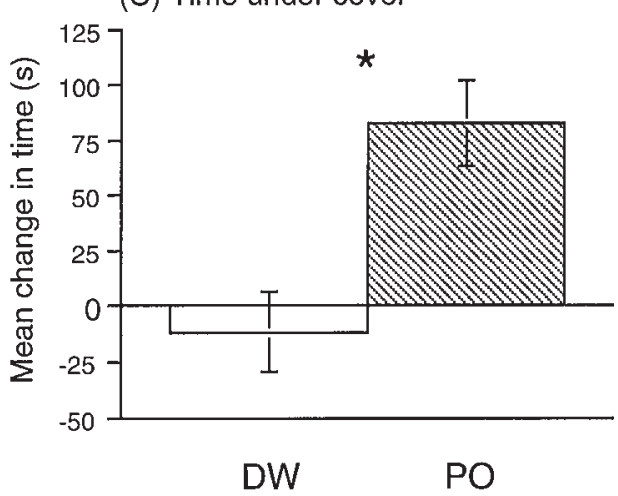

minute during both the pre- and post-stimulus observation periods (total of 20 shrimp). During both pre- and post-stimulus observation periods, we recorded (i) time individuals spent under the cover object, (ii) area use, as described in experiment 1, (iii) time until the first food item was consumed, and (iv) total number of food items consumed. We also recorded the frequency of occurrence of freezing behaviour (as described in experiment 1).

We injected $15 \mathrm{~mL}$ of DW for control trials and $15 \mathrm{~mL}$ of PO for experimental trials. Control trials began at $\sim 8: 30$ a.m.; experimental trials began at 1:00 p.m. on the same day. We tested a total of 18 trout, individually.

For time spent under cover, time to capture the first food item, and total number of food items consumed, we calculated the difference between the pre- and post-stimulus observation periods. We then compared these differences between control and experimental treatments using a Mann-Whitney $U$-test (Siegel 1956). The difference in occurrence of freezing behaviour between control and experimental trials was compared with a Fisher exact probability test (Siegel and Castellan 1988). If acquired predator recognition had occurred, we predicted that the trout would exhibit significantly increased antipredator behaviour when presented with PO alone (compared with DW controls).

\section{Experiment 3. Acquired predator recognition, 21 days postconditioning}

To determine if trout could retain the ability to recognize the chemical cue of a potential predator, we tested nine individual trout that had been held for 21 days after conditioning. The test tanks, experimental protocol, and statistical analyses were as described in experiment 2.
(B) Food items eaten

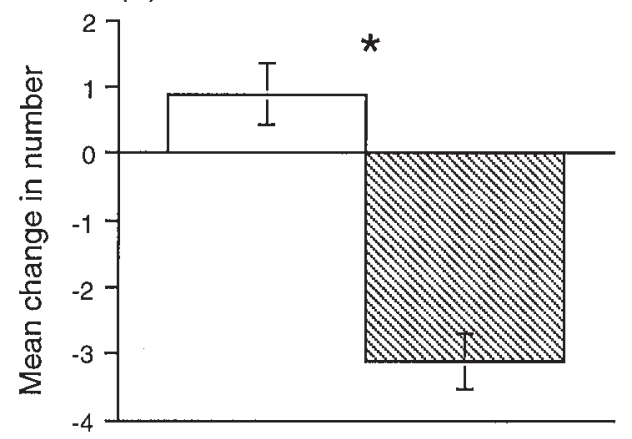

(D) Area use

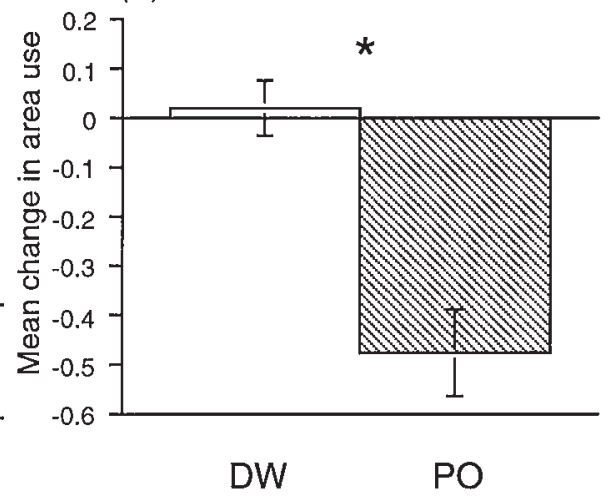

Table 1. Occurrences of freezing behaviour in control versus experimental trials (see text for details).

\begin{tabular}{|c|c|c|c|}
\hline & Yes & No & $P^{*}$ \\
\hline \multicolumn{4}{|c|}{ Experiment 2 (4 days postconditioning) } \\
\hline DW & 0 & 18 & \\
\hline $\mathrm{PO}$ & 7 & 11 & $\leq 0.004$ \\
\hline \multicolumn{4}{|c|}{ Experiment 3 (21 days postconditioning) } \\
\hline DW & 0 & 9 & \\
\hline $\mathrm{PO}$ & 5 & 4 & $\leq 0.02$ \\
\hline
\end{tabular}

\section{Results}

\section{Experiment 1. Conditioning trials}

When presented with a mixed stimulus of TSE + PO, trout exhibited significant increases in antipredator behaviour. Trout significantly increased their time to consume the first food item when exposed to TSE + PO, but not to the DW + PO control $\left(U_{n 1=n 2=6}=36.0, P<0.004\right.$; Fig. 1A). Similarly, trout in the experimental trials exhibited a significant decrease in the number of food items consumed $\left(U_{n 1=n 2=6}=34.0, P<0.01\right.$; Fig. 1B) and the mean number of individuals eating $\left(U_{n 1=n 2=6}=\right.$ 36.0, $P<0.004$; Fig. 1C) when compared with the control trials.

Area use was significantly reduced $\left(U_{n 1=n 2=6}=36.0, P<\right.$ 
Fig. 3. Change in response to DW (open bars) and to PO (solid bars) for each of the behavioural measures recorded in experiment 3. *Significant difference at $P<0.05$ (Mann-Whitney $U$-test) between DW control and PO experimental trials. Data are presented as mean \pm SE for clarity. Nonparametric statistics were used for the analysis (see text for details).

(A) Time to capture first food

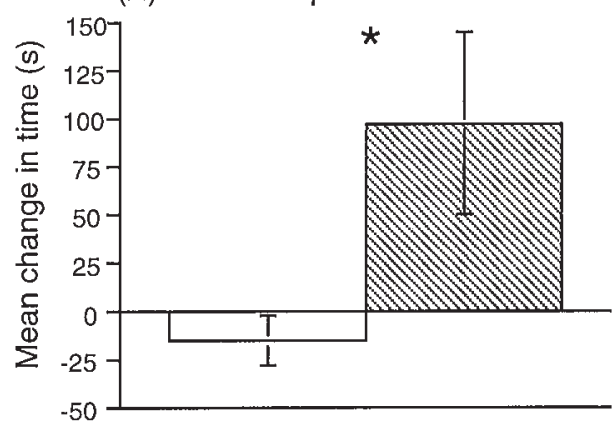

(C) Time under cover

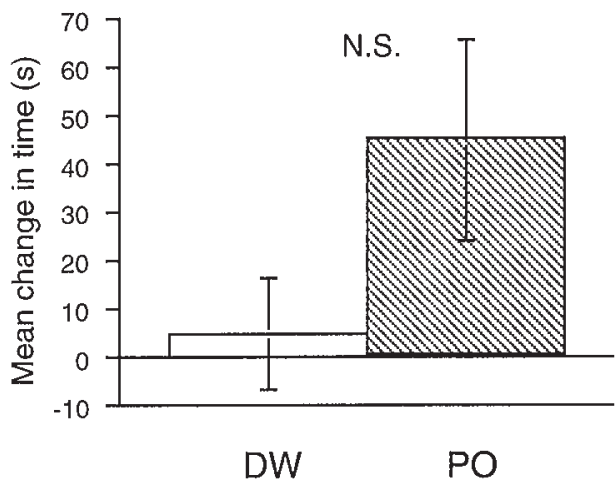

0.004; Fig. 1D) and shoaling index was significantly increased $\left(U_{n 1=n 2=6}=36.0, P<0.004\right.$; Fig. $\left.1 \mathrm{E}\right)$ in the experimental trials when compared with the control trials. Finally, significantly more trout exhibited freezing behaviour in the experimental versus the control trials $\left(U_{n 1=n 2=6}=33.0, P<0.007\right.$; Fig. $\left.1 \mathrm{~F}\right)$. These data demonstrated that juvenile trout responded to TSE with increased antipredator behaviour, confirming the results of Brown and Smith (1997), and that hatchery-reared trout do not recognize PO as a predation threat (i.e., are predator naive).

\section{Experiment 2. Acquired predator recognition, 4 days postconditioning}

When presented with PO alone, trout that were exposed to TSE + PO only once exhibited significant increases in antipredator behaviour. Previously conditioned trout significantly increased the time to capture the first food item $\left(U_{n 1=n 2=18}=\right.$ 317.5, $P<0.0001$; Fig. 2A), reduced the total number of food items consumed $\left(U_{n 1=n 2=18}=311.0, P<0.0001 ;\right.$ Fig. $\left.2 \mathrm{~B}\right)$, increased the amount of time spent under the cover object $\left(U_{n 1=n 2=18}=262.5, P<0.002\right.$; Fig. $\left.2 \mathrm{C}\right)$, and decreased area use $\left(U_{n 1=n 2=18}=289.0, P<0.0001\right.$; Fig. $\left.2 \mathrm{D}\right)$ when presented with PO compared with DW controls. In addition, significantly more occurrences of freezing behaviour were observed in those exposed to PO compared with DW (Table 1).

\section{Experiment 3. Acquired predator recognition, 21 days postconditioning}

When presented with PO alone 21 days after the conditioning
(B) Food items eaten

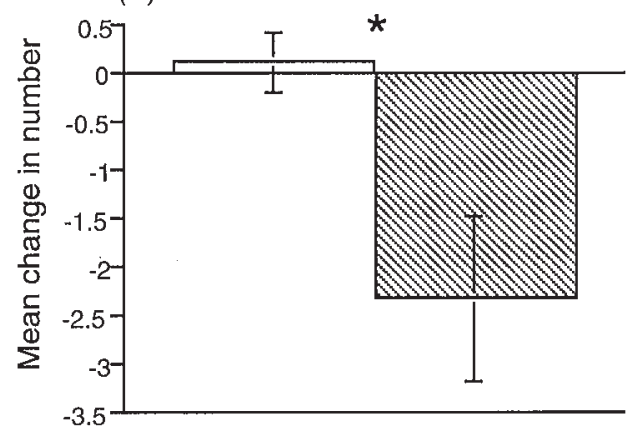

(D) Area use

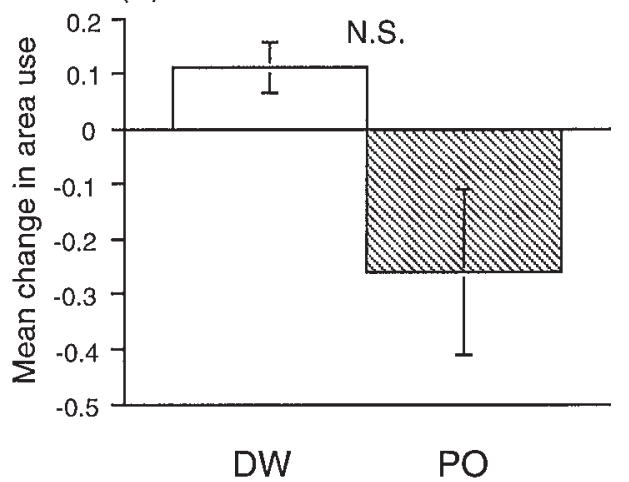

trials, trout still exhibited increased antipredator responses. Trout significantly increased the time to capture the first food item $\left(U_{n 1=n 2=9}=66.0, P<0.03\right.$; Fig. $\left.3 \mathrm{~A}\right)$ and significantly decreased the total number of shrimp consumed $\left(U_{n 1=n 2=9}=67.0\right.$, $P<0.02$; Fig. 3B) when exposed to PO alone compared with DW controls. Significant increases in freezing behaviour were also observed in those exposed to PO alone compared with DW controls (Table 1).

No significant difference was observed between conditioned trout exposed to DW or PO for time spent under cover objects $\left(U_{n 1=n 2=9}=58.5, P=0.12\right.$; Fig. $\left.3 \mathrm{C}\right)$ or area use $\left(U_{n 1=n 2=9}=52.0, P=0.31 ;\right.$ Fig. 3D $)$, although the observed trends were in the predicted direction.

\section{Discussion}

These data clearly demonstrate that juvenile hatchery-reared rainbow trout can learn to recognize $\mathrm{PO}$ as a predation threat when it is paired with conspecific skin extract. This recognition is achieved through a process of releaser-induced recognition learning. After only a single exposure, the trout were able to retain this acquired predator recognition, although at a reduced intensity, for a period of at least 3 weeks.

Experience with predators has been shown to significantly increase the probability of survival in a variety of salmonids. Kanid'hev et al. (1970) reported that naive hatchery chum salmon (Oncorhynchus keta) were preyed upon up to $30 \%$ more often than similar-sized wild salmon. Shortly after release, this difference dropped to between 12 and $18 \%$, and 
4 weeks after release, there was no significant difference between wild and hatchery-reared fish. Ginetz and Larkin (1976), Patten (1977), Olla and Davis (1989), and Berejikian (1995) have shown similar results in a variety of salmonids. All demonstrated that juveniles that have survived initial exposure to predators are more likely to survive subsequent encounters than are naive individuals. The results of Kanid'hev et al. (1970) suggest that the critical period for hatchery-reared salmonids is within the first few weeks of release. If they can survive this initial period, they may be able to acquire the recognition of potential predators and exhibit appropriate antipredator responses upon encounter of a predator. In this light, the retention of acquired predator recognition for a period of at least 3 weeks (as shown by our data) is likely sufficient to increase survival of stocked rainbow trout.

Our data suggest that by conditioning naive hatchery-reared trout to exhibit antipredator responses to the cues of a predator prior to their release, survival could be increased. Prerelease conditioning would likely reduce the learning curve of acquired predator recognition (as in Kanid'hev et al. 1970; Suboski and Templeton 1989; Healey and Reinhardt 1991). Our results suggest that chemical cues may be an effective means by which naive hatchery-raised salmonids could be conditioned to recognize predators. Chivers and Smith (1994a, $1994 b$ ) have successfully conditioned fathead minnows to respond to both the visual and chemical cues of a predator. Whether or not salmonids can be conditioned to respond to the visual cues of a predator using chemical alarm signals remains to be tested.

Upon release, the benefits of acquired predator recognition may be magnified by a mechanism of cultural transmission. Cultural transmission of behaviour is defined as the adoption of a novel behaviour by observing other individuals (conspecifics or heterospecifics) performing the behaviour (Mainardi 1980; Curio 1988; Mineka and Cook 1988; Mathis et al. 1996). Mathis et al. (1996) have shown intra- and inter-specific cultural transmission of antipredator behaviours in fathead minnows and brook sticklebacks (Culaea inconstans).

Juvenile salmonids are often released in high numbers within a limited area (Shively et al. 1996). As a result, predators, not normally specializing on juvenile salmonids, may be induced to shift their diet choice to this new, highly abundant, and profitable food source (Ruggerone and Rogers 1984; Fresh and Schroder 1987; Lyons 1987; Shively et al. 1996). Dense aggregations of stocked salmonids could facilitate the cultural transmission of predator recognition. As a result, the effects of prerelease acquired predator recognition could be magnified upon stocking. In summary, we successfully conditioned predator-naive, hatchery-reared rainbow trout to recognize the chemical cues of a predatory northern pike. Our data suggest that this may be an effective means to reduce poststocking mortality of hatchery-reared salmonids.

\section{Acknowledgments}

The authors wish to thank Jean-Guy J. Godin, Reehan Mirza, Mike Healy, a consulting editor, and an anonymous referee for their helpful comments on earlier versions of the manuscript. Financial support was provided by the Canadian Department of Fisheries and Oceans, the Natural Sciences and
Engineering Research Council of Canada, and the University of Saskatchewan.

\section{References}

Berejikian, B.A. 1995. The effects of hatchery and wild ancestry and experience on the relative ability of steelhead trout fry (Oncorhynchus mykiss) to avoid a benthic predator. Can. J. Fish. Aquat. Sci. 52: 2476-2482.

Brown, G.E., and Godin, J.-G.J. 1997. Anti-predator responses to conspecific and heterospecific skin extracts by threespine sticklebacks: alarm pheromones revisited. Behaviour, 134: 1123-1134.

Brown, G.E., and Smith, R.J.F. 1997. Conspecific skin extracts elicit antipredator responses in juvenile rainbow trout (Oncorhynchus mykiss). Can. J. Zool. 75: 1916-1922.

Brown, G.E., Chivers, D.P., and Smith, R.J.F. 1995a. Fathead minnows avoid conspecific and heterospecific alarm pheromone in the faeces of northern pike. J. Fish Biol. 47: 387-393.

Brown, G.E., Chivers, D.P., and Smith, R.J.F. 1995b. Localized defecation by pike (Esox lucius): a response to labelling by cyprinid alarm pheromone? Behav. Ecol. Sociobiol. 36: 105-110.

Chivers, D.P., and Smith, R.J.F. 1994a. Fathead minnows, Pimephales promelas, acquire predator recognition when alarm substance is associated with the sight of unfamiliar fish. Anim. Behav. 48: 597-605.

Chivers, D.P., and Smith, R.J.F. 1994b. The role of experience and chemical alarm signalling in predator recognition by fathead minnows, Pimephales promelas. J. Fish Biol. 44: 273-285.

Chivers, D.P., Brown, G.E., and Smith, R.J.F. 1995. Acquired predator recognition of predator odour by brook sticklebacks. Ethology, 99: $234-242$.

Curio, E. 1988. Cultural transmission of enemy recognition in birds. In Social learning: psychological and biological perspectives. $E d$ ited by T.R. Zentall and B.G. Galef. Lawrence Erlbaum Associates, Hillside, N.J. pp. 75-98.

Fresh, K.L., and Schroder, S.L. 1987. Influence of the abundance, size, and yolk reserves of juvenile chum salmon (Oncorhynchus keta) on predation by freshwater fishes in a small coastal stream. Can. J. Fish. Aquat. Sci. 44: 236-242.

García, C., Rolán-Alvarez, E., and Sánchez, L. 1992. Alarm reaction and alert state in Gambusia affinis (Pisces, Poeciliidae) in response to chemical stimuli from injured conspecifics. J. Ethol. 10: 41-46.

Ginetz, R.M., and Larkin, P.A. 1976. Factors affecting rainbow trout (Salmo gairdneri) predation on migrant fry of sockeye salmon (Oncorhynchus nerka). J. Fish. Res. Board Can. 33: 19-24.

Hazlett, B.A. 1997. The organisation of behaviour in hermit crabs: response to variation in stimulus strength. Behaviour, 134: 59-70.

Healey, M.C., and Reinhardt, U. 1991. The effectiveness of training hatchery raised chinook and coho salmon to avoid predators. Contract Report, Westwater Research Centre, University of British Columbia, Vancouver, B.C.

Heczko, E., and Seghers, B.H. 1981. Effects of alarm substance on schooling in the common shiner (Notropis cornutus, Cyprinidae). Environ. Biol. Fishes, 6: 25-29.

Hugie, D.M., Thuringer, P.L., and Smith, R.J.F. 1991. The response of the tidepool sculpin, Oligocottus maculosus, to chemical stimuli from injured conspecifics, alarm signalling in the Cottidae (Pisces). Ethology, 89: 322-334.

Kanayama, Y. 1968. Studies of the conditioned reflex in lower vertebrates. X. Defensive conditioned reflex of chum salmon fry in a group. Mar. Biol. 2: 77-87.

Kanid'hev, A.N., Kostyunin, G.M., and Salmin, S.A. 1970. Hatchery propagation of the pink and chum salmons as a means of increasing the salmon stocks of Sakhalin. J. Ichthyol. 10: 249-259.

Krause, J. 1993. The effect of "Schreckstoff" on the shoaling 
behaviour of the minnow: a test of Hamilton's selfish herd theory. Anim. Behav. 45: 1019-1024.

Lawrence, B.J., and Smith, R.J.F. 1989. Behavioral response of solitary fathead minnows, Pimephales promelas, to alarm substance. J. Chem. Ecol. 15: 209-219.

Lebedeva, N.Ye., Vosilene, M.Z.Ye., and Golovkina, T.V. 1994. Aspects of stress in rainbow trout, Salmo gairdneri, release of chemical alarm signals. J. Ichthyol. 33: 66-74.

Lyons, J. 1987. Prey choice among piscivorous juvenile walleyes (Stizostedion vitreum). Can. J. Fish. Aquat. Sci. 44: 758-764.

Magurran, A.E. 1989. Acquired recognition of predator odour in the European minnow (Phoxinus phoxinus). Ethology, 82: 216-223.

Mainardi, D. 1980. Tradition and the social transmission of behaviour in animals. In Sociobiology: beyond nature/nuture? Edited by G.W. Barlow and J. Silverberg. Westview Press, Boulder, Co. pp. 227-255.

Mathis, A., and Smith, R.J.F. 1993a. Intraspecific and cross-superorder responses to chemical alarm signals by brook stickleback. Ecology, 74: 2395-2404.

Mathis, A., and Smith, R.J.F. 1993b. Fathead minnows, Pimephales promelas, learn to recognize northern pike, Esox lucius, as predators on the basis of chemical stimuli from minnows in the pike's diet. Anim. Behav. 46: 645-656.

Mathis, A., Chivers, D.P., and Smith, R.J.F. 1996. Cultural transmission of predator recognition in fishes: intraspecific and interspecific learning. Anim. Behav. 51: 185-201.

Mineka, S., and Cook, M. 1988. Social learning and the acquisition of snake fear in monkeys. In Social learning: psychological and biological perspectives. Edited by T.R. Zentall and B.G. Galef. Lawrence Erlbaum Associates, Hillside, N.J. pp. 51-74.

Olla, B.L., and Davis, M.W. 1989. The role of learning and stress in predator avoidance of hatchery-reared coho salmon (Oncorhynchus kisutch) juveniles. Aquaculture, 76: 209-214.

Patten, B.G. 1977. Body size and learned avoidance as factors affecting predation on coho salmon, Oncorhynchus kisutch, fry by torrent sculpin, Cottus rhotheus. Fish. Bull. U.S. 75: 457-459.

Ruggerone, G.T., and Rogers, D.E. 1984. Arctic char predation on sockeye salmon smolts at Little Togiak River, Alaska. Fish. Bull. U.S. 82: 401-410.
Shively, R.S., Poe, T.P., and Sauter, S.T. 1996. Feeding response by northern squawfish to a hatchery release of juvenile salmonids in the Clearwater River, Idaho. Trans. Am. Fish. Soc. 125: 230-236.

Siegel, S. 1956. Nonparametric statistics for the behavioral sciences. McGraw-Hill, New York.

Siegel, S., and Castellan, N.J. 1988. Nonparametric statistics for the behavioral sciences. 2nd ed. McGraw-Hill, New York.

Smith, R.J.F. 1979. Alarm reaction of Iowa and johnny darters (Etheostoma, Percidae, Pisces) to chemicals from injured conspecifics. Can. J. Zool. 57: 1278-1282.

Smith, R.J.F., 1982. Reaction of Percina nigrofasciata, Ammocrypta beani, and Etheostoma swaini (Percidae, Pisces) to conspecific and intergeneric skin extracts. Can. J. Zool. 60: 1067-1072.

Smith, R.J.F. 1989. The response of Asterropteryx semipunctatus and Gnatholepis anjerensis (Pisces, Gobiidae) to chemical stimuli from injured conspecifics, an alarm response in gobies. Ethology, 81: 279-290.

Smith, R.J.F. 1992. Alarm signals in fishes. Rev. Fish Biol. Fish. 2: 33-63.

Smith, R.J.F., Lawrence, B.J., and Smith, M.J. 1991. Cross-reactions to skin extract between two gobies, Asterropteryx semipunctatus and Brachygobius sabanus. J. Chem. Ecol. 17: 2253-2259.

Suboski, M.D. 1990. Releaser-induced recognition learning. Psychol. Rev. 97: 271-284.

Suboski, M.D. 1992a. Releaser-induced recognition learning by amphibians and reptiles. Anim. Learn. Behav. 20: 63-82.

Suboski, M.D. 1992b. Releaser-induced recognition learning by gastropod molluscs. Behav. Proc. 27: 1-26.

Suboski, M.D., and Templeton, J.J. 1989. Life skills training for hatchery fish: social learning and survival. Fish. Res. 7: 343-352.

Thompson, R.B. 1966. Effects of predator avoidance conditioning on the post-release survival rate of artificially propagated salmon. Ph.D. thesis, University of Washington, Seattle, Wash.

Wisenden, B.D., Chivers, D.P., Brown, G.E., and Smith, R.J.F. 1995. The role of experience in risk assessment: avoidance of areas chemically labeled with fathead minnow alarm pheromone by conspecifics and heterospecifics. Ecoscience, 2: 116-122. 